\title{
MC1R wt Allele
}

National Cancer Institute

\section{Source}

National Cancer Institute. MC1R wt Allele. NCI Thesaurus. Code C52084.

Human MC1R wild-type allele is located in the vicinity of $16 q 24.3$ and is approximately 17 $\mathrm{kb}$ in length. This allele, which encodes melanocyte-stimulating hormone receptor protein, is involved in melanocyte-stimulated hormone signaling which controls melanogenesis. Certain allelic variants of the MCR1 gene are associated with susceptibility to UV-induced skin damage and melanoma. 